Jurnal Simbolika: Research and Learning in Communication Study, 6 (2) Oktober 2020

ISSN 2442-9198 (Print) ISSN 2442-9996 (Online)

JURNAL SIMBOLIKA

Research and Learning in Communication Study

Available online http://ojs.uma.ac.id/index.php/simbolika

DOI : https://doi.org/10.31289/simbollika.v6i2.4089

\title{
Komunikasi Persuasif Satuan Polisi Pamong Praja Surabaya dalam Menertibkan Penyandang Masalah Kesejahteraan Sosial
}

\section{Persuasive Communication Surabaya Civil Service Police Unit in Ordering Persons with Social Welfare Problems}

\author{
Arifah Putri Sabillah* \& Fitria Widiyani Roosinda \\ Program Studi Ilmu Komunikasi, Fakultas Ilmu Sosial dan Politik, \\ Universitas Bhayangkara Surabaya, Indonesia \\ Diterima: 01 Agustus 2020; Disetujui: 25 Oktober 2020; Dipublish: 31 Oktober 2020 \\ *Corresponding email: bellagiki@gmail.com
}

\begin{abstract}
Abstrak
Tujuan dari penelitian ini adalah untuk mengetahui mengukur efektivitas komunikasi persuasif Satpol PP Kota Surabaya dalam menertibkan Penyandang Masalah Kesejahteraan Sosial. Jenis penelitian ini adalah penelitian kuantitatif deskriptif yaitu penelitian yang bertujuan untuk menggambarkan atau melakukan deskrpsi angka-angka yang telah diolah sesuai standardisasi tertentu. Metode penelitian deskriptif ini dilakukan untuk mengetahui keberadaan variabel mandiri, baik hanya pada satu variabel atau lebih (variabel yang berdiri sendiri atau variabel bebas) tanpa membuat perbandingan variabel itu sendiri dan mencari hubungan dengan variabel lain. Hasil dari penelitian ini adalah Efektivitas Komunikasi Persuasif Satpol PP Kota Surabaya dalam menertibkan PMKS berhasil apabila mencapai $70 \%$, dan hasil perhitungan yang telah dilakukan diketahui mencapai 84\%. Maka dapat disimpulkan bahwa komunikasi persuasif Satpol PP Kota Surabaya dalam menertibkan Penyandang Masalah Kesejahteraan Sosial efektif. Kesimpulan bahwa tingginya jumlah PMKS karena Urbanisasi yang dilakukan tidak diimbangi dengan lapangan pekerjaan yang memadai. Bertambahnya jumlah ini juga memberikan tanda bahwa komunikasi persuasif yang dilakukan oleh Satpol PP kepada masyarakat telah berhasil karena terciptanya ketentraman dan ketertiban umum di lingkungan sekitarnya. Sesuai dengan hasil penelitian dinyatakan bahwa tingkat keefektifitasan komunikasi persuasif Satpol PP Kota Surabaya dalam menertibkan Penyandang Masalah Kesejahteraan Sosial yaitu efektif. Dapat diliat dari hasil presentase yang diperoleh mencapai 84\%.

Kata Kunci: Komunikasi Persuasif; Penertiban; Penyandang Masalah Kesejahteraan Sosial.
\end{abstract}

\begin{abstract}
The purpose of this study was to determine the effectiveness of Surabaya City Satpol PP persuasive communication in curbing Persons with Social Welfare Problems. This type of research is descriptive quantitative research, namely research that aims to describe or describe the numbers that have been processed according to certain standards. This descriptive research method was conducted to determine the existence of independent variables, either only in one or more variables (independent variables or independent variables) without making comparisons of the variables themselves and looking for relationships with other variables. The result of this research is the effectiveness of Persuasive Communication of Satpol PP of Surabaya City in controlling PMKS when it reaches 70\%, and the results of calculations that have been done are known to reach $84 \%$. So it can be concluded that the persuasive communication of the Surabaya City Satpol PP in curbing Persons with Social Welfare Problems is effective. The conclusion is that the high number of $P M K S$ due to urbanization is not being matched by adequate employment opportunities. The increase in this number also shows that the persuasive communication carried out by the Satpol PP to the community has been successful because of the creation of peace and public order in the surrounding environment. In accordance with the results of the study stated that the level of effectiveness of the Surabaya City Satpol PP persuasive communication in curbing Persons with Social Welfare Problems is effective. It can be seen from the percentage results obtained reaching 84\%.
\end{abstract}

Keywords: Persuasive Communication; Discipline; People With Social Welfare Problems.

How to Cite: Sabillah, A.P. \& Roosinda, F.W. (2020). Komunikasi Persuasif Satuan Polisi Pamong Praja Surabaya dalam Menertibkan Penyandang Masalah Kesejahteraan Sosial. Jurnal Simbolika: Research and Learning in Communication Study, 6 (2): 165-175 


\section{PENDAHULUAN}

Komunikasi adalah suatu aktivitas penyampaian informasi, dalam bentuk pesan, ide, dan gagasan dari satu pihak ke pihak lainnya (Pengertian-Komunikasi, n.d.). Komunikasi merupakan faktor fundamental yang dibutuhkan untuk mencapai suatu tujuan menjalin suatu komunikasi yang baik dengan masyarakat. Menurut Nurudin (2016) definisi komunikasi, yakni: "Komunikasi adalah proses dimana suatu ide dialihkan dari sumber kepada satu penerima atau lebih, dengan maksud untuk mengubah tingkah laku mereka."

Menurut Hubeis \& Musa (2012) Komunikasi adalah proses penyampaian suatu pesan oleh seseorang kepada orang lain untuk memberitahu atau untuk mengubah sikap, pendapat, atau perilaku, baik langsung (secara lisan) maupun tidak langsung (melalui media). Teknik komunikasi merupakan suatu proses atau upaya komunikasi dalam membangun atau membuat suatu rencana yang akan dilakukan nantinya, guna menciptakan sebuah kinerja yang baik.

Komunikasi persuasif dipercaya menjadi salah satu solusi guna meniadakan dinamika-dinamika tersebut. Komunikasi persuasif adalah interaksi antara dua orang atau lebih yang mengedapankan pendekatan berupa ajakan atau bujukan guna mencapai pemaknaan yang sama diantara kedua belah pihak. Metode komunikasi persuasif yang baik disampaikan dengan bahasa yang baik dan mudah dimengerti. Menurut Hanurawan (2015) persuasif adalah suatu usaha secara cermat dari satu orang atau suatu kelompok untuk mempengaruhi keyakinan, sikap, dan perilaku orang lain atau kelompok lain pada arah tertentu.

Efektifitas proses persuasi sangat bergantung pada keberhasilan proses. Menurut Maulana (2013) persuasi adalah kegiatan psikologis dalam usaha mempengaruhi sikap, sifat, pendapat dan perilaku seseorang atau orang banyak, mempengaruhi sikap, sifat, pendapat dan perilaku dapat dilakukan dengan beberapa cara mulai teror, boikot, pemerasan, penyuapan, dan sebagainya dapat juga memaksa orang lain bersikap atau berperilaku seperti yang diharapkan.

Menurut Myers (2012) persuasif adalah proses dimana sebuah pesan menyebabkan perubahan keyakinan, sikap, atau perilaku. Proses komunikasi yang efektif membutuhkan kesatuan situasi antara pengirim pesan dan penerima pesan tentang isi suatu pesan. Faktor komunikasi mempengaruhi efektivitas pesan adalah kemampuan isi pesan untuk menimbulkan rasa cemas, penarikan secara eksplisit isi pesan oleh penerima, dan kecenderungan 
isi pesan untuk mengarahkan kebenaran isi pesan hanya dari satu sisi.

Menurut Mardiasmo

efektivitas adalah ukuran berhasil tidaknya pencapaian tujuan suatu organisasi mencapai tujuannya. Menurut Pekei (2016) efektivitas adalah hubungan antara output dan tujuan merupakan ukuran seberapa jauh tingkat output, kebijakan dan prosedur dari organisasi.

Efektivitas komunikasi persuasif adalah proses penyampaian suatu pesan oleh seseorang kepada orang lain untuk memberitahu atau untuk mengubah sikap, pendapat, atau perilaku, baik langsung (secara lisan) maupun tidak langsung dimana sebuah pesan menyebabkan perubahan keyakinan, sikap, atau perilaku dengan pencapaian pesan yang mempunyai tujuan dari isi pesan tersebut dan memberikan umpan balik (feed back) atau reaksi sehingga pesan pun berhasil tersampaikan dan menimbulkan sebuah komunikasi yang efektif.

Dalam menyikapi masalah sosial di Kota Surabaya, Pemerintah Kota Surabaya memberikan perhatian kepada penyandang masalah kesejahteraan sosial di Kota Surabaya. Penyandang masalah kesejahteraan sosial adalah seseorang, keluarga atau masyarakat yang karena suatu hambatan, kesulitan, atau gangguan yang tidak dapat melaksanakan fungsi sosialnya, sehingga tidak dapat terpenuhi kebutuhan hidupnya baik jasmani, rohani dan sosial secara mewadai dan wajar.

Penanganan para Penyandang Masalah Kesejahteraan Sosial (PMKS) seharusnya menjadi salah satu program prioritas pemerintah. Hal ini sudah tertuang dalam Pasal 34 Ayat (1) UndangUndang Dasar 1945, dan Pancasila sebagai dasar negara terutama sila ke-5 yang dikuatkan oleh UU No 11 Tahun 2009 Tentang Kesejahteraan Sosial.

Penyelenggaraan kesejahteraan sosial bertujuan untuk meningkatkan taraf kesejahteraan, kualitas, kelangsungan hidup, dan memulihkan fungsi sosial dalam rangka mencapai kemandirian. Untuk meningkatkan ketahanan sosial masyarakat, menangani masalah kesejahteraan sosial, meningkatkan kemampuan, kepedulian, dan tanggungjawab sosial dunia usaha dalam penyelenggaraan kesejahteraan sosial secara melembaga dan berkelanjutan.

Dalam Peraturan Daerah Nomor 14 Tahun 2016 Tentang Pembentukan dan Susunan Perangkat Daerah Kota Surabaya, bahwa kedudukan Satpol PP Kota Surabaya adalah unsur penunjang Pemerintah Daerah yang dipimpin oleh Kepala Satuan yang berada dibawah dan bertanggung jawab langsung kepada Kepala Daerah. 
Teknik yang paling dominan digunakan dalam pembinaan mental karena sering memberikan pemahaman kepada pengemis dengan cara memberikan sebuah gambaran atau ilustrasi tertentu untuk menarik perhatian pengemis sehingga dapat menimbulkan sikap ingin tahu dan penasaran. Dengan adanya sikap ketertarikan yang dimunculkan pengemis maka diharapkan pengemis dapat merubah sikap dan perilakunya.

Tujuan dari penelitian ini adalah untuk mengetahui mengukur efektivitas komunikasi persuasif Satpol PP Kota Surabaya dalam menertibkan PMKS (Penyandang Masalah Kesejahteraan Sosial). Jenis pekerjaan yang menjadi kategori PMKS seperti menjadi anak jalanan, Wanita Tuna Susila (WTS), pengemis atau gelandangan.

\section{METODE PENELITIAN}

Penelitian ini menggunakan metodologi kuantitatif. Penelitian kuantitatif sesuai dengan namanya, banyak dituntut menggunakan angka mulai dari pengumpulan data, penafsiran terhadap data tersebut, serta penampilan hasilnya (Arikunto, 2013). Jenis penelitian ini adalah penelitian kuantitatif deskriptif yaitu penelitian yang bertujuan untuk menggambarkan atau melakukan deskripsi angka-angka yang telah diolah sesuai standardisasi tertentu.

Metode penelitian deskriptif ini dilakukan untuk mengetahui keberadaan variabel mandiri, baik hanya pada satu variabel atau lebih (variabel yang berdiri sendiri atau variabel bebas) tanpa membuat perbandingan variabel itu sendiri dan mencari hubungan dengan variabel lain (Sugiyono, 2017). Untuk menentukan indikator, peneliti perlu menentukan variabel terlebih dahulu. Variabel adalah objek penelitian, atau apa yang menjadi titik perhatian suatu penelitian. Dalam penelitian ini terdapat dua variabel yaitu: (1) Variabel Bebas (Independent Variable); dan (2) Variabel Terikat (Dependent Variable) (Suharsaputra, 2018).

Variabel bebas (Independent variable), adalah variabel bebas yang mempengaruhi varibel lainnya. Dalam penelitian ini yang menjadi variabel bebas adalah efektivitas komunikasi persuasif (X); Variabel terikat (Dependent variable) merupakan variabel yang dipengaruhi oleh variabel lain. Dalam penelitian ini yang menjadi variabel terikat adalah menertibkan PMKS (Y).

Unit Analisis pada penelitian ini adalah Masyarakat dan Anggota Satpol PP Kota Surabaya. Teknik pengumpulan datanya melakukan pembagian kuesioner (angket), melakukan interview 
(wawancara), dan observasi. Teknik analisa data yang digunakan dalam penelitian ini dimaksud untuk menghasilkan data yang akurat yaitu Skala Likert. Penelitian ini menggunakan kuesioner sebagai pengumpulan datanya. Pendapat lain mengatakan: "Kuesioner merupakan teknik pengumpulan data yang dilakukan dengan cara memberi seperangkat pertanyaan atau pernyataan tertulis kepada responden untuk dijawabnya (Sugiyono, 2018)."

Dalam kuesioner ini menggunakan skala likert, dengan skala likert responden diminta untuk melengkapi kuesioner yang mengharuskan mereka untuk menunjukkan tingkat persetujuannya terhadap serangkaian pertanyaan.

Berdasarkan data yang diperoleh dari hasil kuesioner yang diberikan kepada responden, kemudian dilakukan pengujian terhadap instrumen untuk mengukur tingkat kebaikan instrumen maka dapat dilakukan uji validitas dan reliabilitas. Validitas menunjukkan sejauh mana relevansi pertanyaan terhadap apa yang ditanyakan atau apa yang ingin diukur dalam penelitian.

Menurut Sujarweni (2014) menjelaskan bahwa uji reliabilitas dapat dilakukan secara bersama-sama terhadap seluruh butir atau item pertanyaan dalam angket (kuesnioner) penelitian. Adapun dasar pengambilan keputusan dalam uji reliabilitas adalah jika nilai Cronbach Alpha $>$ 0,60 maka kuesnioner atau angket dinyatakan reliabel atau konsisten. Jika nilai Cronbach Alpha $<0,60$ maka kuesnioner atau angket dinyatakan tidak reliabel atau tidak konsisten.

Teknik sampling adalah teknik yang dilakukan untuk menentukan sampel. Jadi, sebuah penelitian yang baik memperhatikan dan menggunakan sebuah teknik dalam menetapkan sampel yang akan diambil sebagai subjek penelitian (Teknik Sampling Dalam Penelitian, n.d.). Teknik sampling yang digunakan oleh peneliti yaitu teknik non-probability sampling dengan tipe accidental sampling. Dimana peneliti memilih responden yang sesuai dengan kriteria yang telah ditetapkan dan tujuan peneliti.

Kriterianya adalah masyarakat yang terjaring oleh Satpol PP Kota Surabaya dan Anggota Satpol PP Kota Surabaya yang menertibkan PMKS. Sampel yang diambil dalam penelitian ini dapat mewakili populasi maka dapat ditentukan jumlah sampel yang dihitung dengan menggunakan rumus Taro Yamane sebagai berikut: 
Keterangan:

$\mathrm{n}=$ Jumlah Sampel

$\mathrm{N}=$ Jumlah Populasi

$\mathrm{e}=$ Persentase Kelonggaran

Ketidaktelitian karena kesalahan pengambilan sampel yang masih dapat ditolerir, dan dalam penelitian ini sebesar $5 \%$.

$$
\begin{aligned}
& \text { Jadi, } \mathrm{n}=\frac{133}{1+(133 \times 0,05)^{2}} \\
& \begin{aligned}
\mathrm{n} & =\frac{133}{1+0,33 \mathrm{n}} \\
& =\frac{133}{} \\
& =1,33 \\
\mathrm{n} & =100 \text { sampel }
\end{aligned}
\end{aligned}
$$

Berdasarkan perhitungan yang sudah dilakukan maka jumlah sampel dalam penelitian ini sebanyak 100 orang sampel yang diambil sebanyak 100 orang yang terdiri dari 50 masyarakat dan 50 anggota Satpol PP Kota Surabaya.

\section{HASIL DAN PEMBAHASAN}

Kota Surabaya sebagai barometer perekonomian di Jawa Timur merupakan daya tarik bagi para pengusaha kecil maupun besar. Oleh karena itu, tidak sedikit masyarakat dari luar Kota Surabaya tertarik untuk datang ke Kota Surabaya. Sehingga meluasnya perkembangan jumlah PMKS di Kota Surabaya selain tekanan kemiskinan dan urbanisasi berkaitan dengan banyak faktor. Penulis menemukan 2 faktor penyebab di balik meluasnya PMKS di Kota Surabaya antara lain: Faktor Internal (Individu) dan Faktor Eksternal.

Faktor Internal (Individu), adalah

Keterampilan. Tekanan kemiskinan di pedesaan yang dialami keluarga miskin menyebabkan mereka tidak memiliki peluang untuk tetap bekerja di desa, sementara saat mereka tidak memiliki alternatif keterampilan yang dapat dijadian bekal untuk menyabung hidup di kota besar. Keluarga, adalah hal yang berkaitan dengan pengaruh dan peran orang tua dalam melakukan pembimbingan terhadap anak. Seperti yang kita ketahui banyak anak-anak di usia yang masih belia lebih memilih untuk mencari uang dijalanan dibandingkan dengan melanjutkan pendidikan diusianya. Ditemui beberapa alasan anak dibawah umur yang menjadi pengamen dengan alasan membantu biaya kehidupan orang tuanya. Pendidikan, merupakan hal penting saat ini yang menjadi latar belakang seseorang dalam mencari pekerjaan. F aktor latar belakang pendidikan menjadi sangat berpengaruh karena pendidikan dianggap sebagai acuan keahlian seseorang, sehingga penting 
adanya pemerataan pendidikan termasuk untuk memperhatikan keluarga kurang mampu agar memperoleh hak yang sama dalam hal pendidikan. Kemiskinan, merupakan factor dasar dari permasalahan kesejahteraan sosial. Dimulai dari keterbatasan pendidikan sampai dengan modal usaha menjadi hal yang banyak ditemui dalam permasalahan kesejahteraan sosial. Modal usaha yang dimaksud bagaimana seseorang mampu untuk menciptakan usahanya sendiri (wiraswasta) namun masih terbatas.

Faktor eksternal ialah faktor yang asalnya dari luar diri seseorang atau individu. Berikut ini merupakan beberapa contoh faktor eksternal yaitu: Terbatasnya Lapangan Pekerjaan, keterbatasan lapangan pekerjaan menjadi penyebab timpangnya angka kemiskinan di perdesaan dan perkotaan. Mengingat populasi manusia meningkat yang berakibat tidak mampu dengan ketersediaan lapangan pekerjaan sehingga terjadi peningkatan pengangguran. Kemampuan kota Surabaya untuk menyediakan fasilitas publik dan lapangan pekerjaan relatif terbatas, sehingga terdampak para migrasi yang tidak mampu mengembangkan pekerjaan produktif yang layak, mereka pada akhirnya terpaksa masuk pada jenis pekerjaan yang termasuk kategori PMKS seperti menjadi anak jalanan, WTS, pengemis atau gelandangan. Urbanisasi adalah perpindahan penduduk dari desa ke kota. Faktor terjadinya urbanisasi yaitu terbatasnya lapangan pekerjaan di desa sehingga menyebabkan penduduk melakukan perpindahan ke kota-kota besar. Seperti halnya Kota Surabaya hampir sebagian besar penduduknya berasal desa sehingga menyebabkan tingginya angka masalah kesejahteraan sosial dikarenakan perpindahan tersebut tidak diimbangi dengan faktor internal sebagian orang sebagai modal hidup di kota. Kesenjangan Nilai Upah Minimum Tiap Daerah, Nilai upah minimum di kota besar lebih tinggi daripada di perdesaan karena tingkat perekonomian di kota besar menjadi barometer perekonomian di suatu provinsi termasuk Kota Surabaya Provinsi Jawa Timur. Kesenjangan nilai upah minimum merupakan pengaruh besar terjadinya masalah kesejahteraan sosial karena semakin banyak perpindahan penduduk desa ke kota maka semakin terbatas pula lapangan pekerjaan dan lahan untuk dijadikan tempat tinggal.

Kemajuan Teknologi, membuat berkurangnya kesempatan kerja di wilayah pedesaan akibat proses komersialisasi dan modernisasi pertanian. Banyak bukti menunjukkan bahwa ketika teknologi 
mulai memasuki wilayah pedesaan khususnya sektor pertanian dan pola hubungan masyarakat desa pelan- pelan mulai berubah makin kontraktual, maka akibat yang tidak terelakkan adalah mulai memudarkan kemampuan involutif sektor pertanian untuk menampung tenaga kerja yang ada, sehingga jalan keluar yang dipilih kemudian adalah mereka mencoba mencari pekerjaan di tempat lain dengan cara berusaha mengadu nasib ke kota-kota besar yang dinilai lebih membuka peluang untuk hidup.

\section{Pelaksana Penertiban}

Pelaksana kegiatan penertiban yang dilakukan oleh Satpol PP Kota Surabaya melalui beberapa kegiatan rutin, yaitu: Patroli, merupakan kegiatan rutin yang dilakukan oleh Satpol PP Kota Surabaya. Ada beberapa tim yang melaksanakan kegiatan patroli rutin yaitu Tim Kaypang, Tim Odong-Odong dan Tim Judge Bao. Tim khusus pada malam hari hingga dini hari diberi nama Tim Asuhan Rembulan dengan didampingi oleh jajaran TNI dan Polri. Dengan adanya patroli rutin tersebut diharapkan mampu untuk menemukan kejadian secara langsung terhadap pelanggaran ketentraman dan ketertiban umum.

Posko Terpadu, merupakan pos yang terdiri dari 4 wilayah yaitu: (1) Pos
Terpadu Wilayah Selatan; (2) Pos Terpadu Wilayah Utara; (3) Pos Terpadu Wilayah Barat; (4) Pos Terpadu Wilayah Timur yang didukung oleh beberapa pos di titik-titik tertentu.

Di posko terpadu Satpol PP bergabung dengan BPB Linmas, Dinas Kesehatan, Dinas Pemadaman Kebakaran, dan Dinas Perhubungan. Keberadaan posko terpadu sebagai upaya cepat untuk menindaklanjuti setiap kejadian yang berada di wilayahnya.

\section{Analisa Data}

Hasil Uji Validitas. Item instrumen yang diajukan kepada seluruh responden bahwa seluruh item dinyatakan valid, dimana Nilai R-Hitung lebih besar dibandingkan dengan R-Tabel yang mempunyai nilai 0,192.

Dari uji reliabilitas yang telah di hitung menggunakan Cronbach's a Alpha, didapatkan nilai 0,910. Nilai ini menunjukkan koefisien reliabilitas $>0,60$ sehingga dapat dikatakan nilai tersebut memiliki kategori reliabilitas sangat tinggi.

Hipotesis kerja yang peneliti ajukan dalam penelitian yang berjudul "Efektivitas Komunikasi Persuasif Satpol PP Kota Surabaya dalam menertibkan PMKS" adalah Efektivitas Komunikasi Persuasif Satpol PP Kota Surabaya dalam menertibkan PMKS paling tinggi 70\%. 
Penguji hipotesis menggunakan rumus t-test satu sampel. Adapun perhitungan penguji hipotesis adalah melalui tahap-tahap berikut:

Skor ideal yang diperoleh dari jawaban pernyataan yang diajukan melalui kuesioner yaitu :

$5 \times 100 \times 16=8.000$

Keterangannya adalah 5 merupakan skor tertinggi dari setiap pernyataan dalam kuesioner, 100 merupakan jumlah sampel, dan 16 merupakan banyaknya pernyataan kuesioner. Rata-rata dari skor ideal peneliti tersebut adalah $8.000: 100=80$. Sedangkan skor penelitian sebesar 6.757. Skor penelitian adalah jumlah total nilai seluruh pertanyaan yang dijawab oleh seluruh responden.

Dengan demikian nilai efektivitas komunikasi persuasif Satpol PP Kota Surabaya dalam menertibkan PMKS adalah $6.757: 8.000=0,84$ atau presentase menjadi 84\%. Sehingga efektivitas komunikasi persuasif Satpol PP Kota Surabaya dalam menertibkan PMKS adalah 84\%. Dalam variabel tentang, efektivitas komunikasi persuasif Satpol PP Kota Surabaya dalam menertibkan PMKS nilai yang dihipotesiskan paling tinggi adalah $70 \%(0,70)$. Hal ini berarti 0,70 x $80=56$. Hipotesis statistiknya dapat dirumuskan sebagai berikut:

$$
\text { На : } \mu 0>70 \%>0,70 \times 80=5 \%
$$

Ho : $\mu_{0}<70 \%<0,70 \times 80=56 \%$

Pengujian hipotesis menggunakan rumus $t$-test satu sampel adalah diketahui:

Ditanya: $\mathrm{t}$ ? Jawab $=\underline{\mathrm{x}-\mu \mathrm{O}}$

$\mathrm{S} \sqrt{\mathrm{n}}$

$=\underline{67,57-56}$

$8,145 / \sqrt{100}$

$=1157$

0,8145

$=14,205$

Harga $t$ hitung tersebut selanjutnya dibandingkan dengan harga t tabel dengan derajat $(\mathrm{dk})=\mathrm{n}-1=100-1=99$ dan taraf kesalahan 5\% untuk uji satu pihak kiri, maka harga t tabelnya adalah 1,660 Dengan hipotesis bahwa:

Jika $\mathrm{t}$ hitung $<\mathrm{t}$ tabel, maka $\mathrm{Ha}$ diterima/H0 ditolak

Jika $\mathrm{t}$ hitung $>\mathrm{t}$ tabel, maka $\mathrm{Ha}$ ditolak/H0 diterima

Hasil penelitian didapatkan bahwa harga t hitung lebih besar dari harga t tabel atau jatuh pada penerimaan $\mathrm{Ha}$ $(14,205>1,660)$ maka Ha ditolak, Ho diterima.

Daerah Penerimaan Ha

Daerah Penerimaan Ho






\section{Interpretasi Data}

Dalam penelitian ini, peneliti berusaha menjawab seberapa besar keefektivitasan komunikasi persuasif Satpol PP Kota Surabaya dalam menertibkan PMKS? Untuk menjawab terdapat langkah untuk menjawab rumusan masalah tersebut.

Langkah pertama, yaitu menentukan skor ideal dan menghitung skor hasil penelitian, skor ideal variabel adalah $5 \mathrm{x}$ $100 \times 16=8.000$. Dimana 5 adalah nilai tertinggi dari pilihan jawaban atas pertanyaan dalam kuesioner. 100 adalah jumlah responden, sedangkan 16 adalah jumlah item pertanyaan yang dibuat oleh peneliti. Skor penelitian yang diperoleh adalah 6.757. Dengan demikian nilai efektivitas komunikasi persuasif Satpol PP Kota Surabaya dalam menertibkan PMKS adalah $6.757: 8.000=0,84$ dan dipresentasekan menjadi 84\%.

\section{Efektivitas Komunikasi Persuasif} Satpol PP Kota Surabaya dalam menertibkan PMKS berhasil apabila mencapai 70\%, dan hasil perhitungan yang telah dilakukan diketahui mencapai 84\%. Maka dapat disimpulkan bahwa komunikasi persuasif Satpol PP Kota Surabaya dalam menertibkan PMKS efektif.

\section{SIMPULAN}

Data yang telah dihimpun oleh penulis dalam penelitian disimpulkan bahwa tingginya jumlah PMKS karena Urbanisasi yang dilakukan tidak diimbangi dengan lapangan pekerjaan yang memadai. Bertambahnya jumlah ini juga memberikan tanda bahwa komunikasi persuasif yang dilakukan oleh Satpol PP kepada masyarakat telah berhasil karena terciptanya ketentraman dan ketertiban umum di lingkungan sekitarnya. Sesuai dengan hasil penelitian dinyatakan bahwa tingkat keefektifitasan komunikasi persuasif Satpol PP Kota Surabaya dalam menertibkan PMKS yaitu efektif. Dapat diliat dari hasil presentase yang diperoleh mencapai $84 \%$.

\section{DAFTAR PUSTAKA}

Arikunto, S. (2013). Prosedur Penelitian: Suatu Pendekatan Praktik. Bandung: Rineka Cipta. Hanurawan, F. (2015). Psikologi Sosial. Bandung: PT Remaja Rosdakarya.

Maulana, H., \& Gumelar, G. (2013). Psikologi Komunikasi dan Persuasi. Jakarta: Akademia Permata.

Pekei, B. (2016). Konsep dan Analisis Efektivitas Pengelolaan Keuangan Daerah di Era Otonomi. Buku 1. Jakarta: Taushia.

Hubeis \& Musa, D. (2012). Komunikasi Profesional, Seperangkat Pengembangan Diri. Bogor; IPB Press.

Mardiasmo. (2017). Akuntansi Sektor Publik. Edisi IV. Jogyakarta: Andi.

Myers, D.G. (2012). Psikologi Sosial. Jakarta; PT. Raja Grafindo Persada.

Nurudin. (2016). Ilmu Komunikasi Ilmiah dan Populer. Jakarta: PT. RajaGrafindo Persada.

Pengertian hipotesis deskriptif. (n.d.). Retrieved October 15, 2019, from https://www.temukanpengertian. com/2013/06/pengertian-hipotesis- 
deskriptif.html. pengertian-komunikasi. (n.d.). Retrieved October 6, 2019, from https://www.maxmanroe.com/vi d/sosial/pengertian- komunikasi.html

Sugiyono. (2012). Metode Penelitian Pendidikan Pendekatan Kuantitatif, Kualitatif, dan R\&D. Bandung: ALFABETA.

Sugiyono. (2017). Metode Penelitian Kuantitatif, Kualitatif, dan R\&D. Bandung: Alfabeta.
Sugiyono, (2018). Metode Penelitian Kuantitatif, Kualitatif, dan R\&D. Bandung: Alfabeta.

Suharsaputra, U. (Ed). (2018). Metode Penelitian Kuantitatif, Kualitatif dan Tindakan. Jakarta: PT. Refika Aditama.

Sujarweni, W.V. (2014). SPSS untuk Penelitian. Jakarta: Pustaka Baru Press. 